\title{
CORRIGENDUM
}

\section{First record of Toxodontidae (Mammalia, Notoungulata) from the late Miocene-early Pliocene of the southern central Andes, NW Argentina- CORRIGENDUM}

\author{
A. Bonini, G. I. Schmidt, M. A. Reguero, E. Cerdeño, A. M. Candela, and N. Solís
}

doi: 10.1017/jpa.2016.160, Published by Cambridge University Press, 21 February, 2017. The sentence on page 567 in the Materials and methods section,
incorrectly stated:

"Years later, Mones (1975) described a juvenile mandibular fragment as Xotodon cf. X. smaltatus, but later the same author regarded this species as a nomen nudum (Mones, 1986)."

The text should read: "Years later, Mones (1975) described a juvenile mandibular fragment as Xotodon cf. X. smaltatus."

The error was due to the fact that Mones (1986) established as nomen nudum the name Xotodon smaltatus in Kraglievich (1931), but not in Kraglievich (1932:296-298, fig.), where the taxon was described and figured, and therefore it cannot be considered nomen nudum at all. See Kraglievich, L., 1931, El despertar de los estudios paleontológicos en la República del Uruguay: Archivos de la Sociedad de Biología de Montevideo, v. 3, p. 32-39.

The editors apologize for this error and thank Dr. A. Mones for alerting them to this unintentional mistake on the part of the authors.

\section{Reference}

Bonini, A., Schmidt, G. I., Reguero, M. A., Cerdeño, E., Candela, A. M., and Solís, N., 2017, First record of Toxodontidae (Mammalia, Notoungulata) from the Late Miocene-Early Pliocene of the southern central Andes, NW Argentina: Journal of Paleontology, v. 91, p. 566-576. doi: 10.1017/ jpa.2016.160. 